\section{A Survey of the Ornamental Horticulture Industry in lowa}

\author{
Cynthia Haynes ${ }^{1}$, Ann Marie VanDerZanden, and Jeffery K. Iles
}

AdDitional INDEX wORDs. retail, nursery, landscape, economic survey

Summary. The ornamental horticulture industry in the United States (the green industry) is a multibillion dollar industry that contributes to the economy of every state. Greenhouse and nursery products rank in the top 10 commodities produced in 42 states. In 2004, a 38-question survey was developed and mailed to 1281 members of Iowa's green industry, including wholesale and retail greenhouses, nurseries and florists, garden centers, landscape designers and contractors, and arborists, to gather information on the scope, scale, and business climate of the green industry in Iowa. All business types were represented in the 117 usable surveys that were returned. Although size and type of businesses varied, a majority of respondents had only one location, were family-owned, and had been in business less than 6 years. Respondents reported few factors that could limit their business success, and most felt they were much stronger than their competitors in the areas of customer perception of product quality and service and ability to meet customer needs. The estimated value of sales and services directly related to Iowa's green industry in 2004 was $\$ 311.5$ million, and a majority of respondents expected their business to grow in the areas of employment, annual gross payroll and sales, and total annual expenses by 2010.

$\mathrm{I}$ n 2004, the U.S. green industry, which includes both production (nursery and greenhouse) and service sectors (landscape design, installation and maintenance, lawn care and tree care), generated $\$ 147.8$ billion in output or sales, which translates to $\$ 95.1$ billion in value-added impacts (Hall et al., 2005). Value-added impact is defined as the output value less the value of purchased inputs used in producing goods or services for final consumption (Hall et al., 2005). Nursery and greenhouse crops are ranked in the top 10 commodities in 42 states and in 2004 ranked as the fourth largest crop group in the United States based on farm cash receipts [U.S. Department of Agriculture (USDA), 2004].

The economic importance of the green industry can be measured in every region of the United States. Although seven states (California, Texas, Florida, North Carolina, Oregon, Ohio, and Maryland) account for almost two-thirds of all nursery crops produced, the value-added

Department of Horticulture, Iowa State University, 106 Horticulture Hall, Ames, IA 50011

This research was supported by the Iowa Nursery and Landscape Association Research Corporation.

We thank Mark Imerman, Extension Program Specialist, Agriculture Economics, and Daniel Otto, Professor of Agriculture Economics, for their assistance in economic analysis.

${ }^{1}$ Corresponding author. E-mail: chaynes@iastate.edu. impact of the green industry is distributed more uniformly across the United States. In 2004, the Midwest realized $\$ 19.2$ billion in total valueadded impacts followed by the Pacific region ( $\$ 18.4$ billion), the Northeast ( $\$ 17.9$ billion), and the Southeast (\$13.5 billion) (Hall et al., 2005). Currently, Iowa ranks last in total outputs among the eight states that comprise the Midwest (Hall et al., 2005 ). Yet, the green industry is the fastest growing segment of Iowa's agriculture industry, and in the past 13 years, the number of private horticulture businesses in Iowa has more than doubled (Klein, 2003).

Iowa's agriculture industry consists of a mix of production agriculture [corn (Zea mays) and soybeans (Glycine max)] as well as relatively small diversified farms specializing in edible food crops, nursery plants, and greenhouse plants. Recent surveys of the turfgrass and edible food crop production sectors showed these horticulture industries are important to Iowa's economy. The turfgrass industry reported over $\$ 1$ billion generated from annual turfgrass maintenance and accounted for almost 81,000 workers in Iowa (National Agricultural Statistics Service, 2001). A 2001 survey of food crop producers found that the nearly 500 growers realized over \$15 million in sales from edible food crops (National Agricultural
Statistics Service, 2002). A survey of Iowa's ornamental horticulture industry has not been completed recently; therefore, this research project was designed to gather and analyze data from members of Iowa's green industry to better understand the scope, scale, and business climate of this industry and to determine its economic impact on Iowa's economy.

\section{Materials and methods}

In consultation with the Iowa Nursery and Landscape Association Research Corporation Board of Directors and the Iowa State University Institutional Review Board, a 38-question survey instrument was developed. Questions were designed to gather information on type of business and demographics of the business owner, employees, sales, sources of other revenue, inventory, factors that impact business success, future expectations, and participation in professional development opportunities. The questionnaire consisted of 18 closed-ended and 20 openended questions. The closed-ended questions were formatted into a 5-point Likert-type scale (Likert, 1932). Before mailing, the questionnaire was reviewed by survey professionals at the Center for Survey and Statistical Methods at Iowa State University. The questionnaire was then administered to a select group of green industry representatives and edited per their suggestions. The mailing list was generated from a combination of the Iowa Department of Agriculture's horticulture grower and dealer license database and membership databases from professional associations (nursery/landscape and florist). Redundancies from the multiple sources were removed.

A total of 1281 businesses were identified: 377 florists and 904 nursery, greenhouse, or landscape related businesses. On 10 Feb. 2005, questionnaires were mailed to all 1281 . On 7 Mar. 2005, a reminder postcard was sent to all nonrespondents, and a targeted mailing of the original questionnaire was sent to the businesses from the original population, identified as nursery, greenhouse, and landscape production or sales. Data collection was completed in July 2005. Questionnaires were coded on receipt and identifying information was removed. Dual entry of data was 
performed by technicians at the Iowa State University Center for Survey and Statistical Methodology for accuracy. Data were analyzed using Proc Freq in SAS (version 8.0; SAS Institute, Cary, NC). Under the direction of an agriculture economics expert (M. Imerman, personal communication), an input-output model was generated and applied to survey responses to estimate the direct value of Iowa's green industry (gross receipts and jobs). Furthermore, using an IMPLAN model for Iowa, the overall economic value of the green industry was estimated.

\section{Results and discussion}

Of the 202 questionnaires returned ( $15.8 \%$ response), 117 contained usable data (56 said they do not sell ornamental plants and 29 respondents were no longer in business). Of the 117 usable questionnaires, $72(61.5 \%)$ were from retail operations (florist, garden center, nursery, or greenhouse), 23 (19.7\%) from landscape contractors, five $(4.3 \%)$ from wholesale operations (florist or nursery), and 17 (14.5\%) were returned from a combination of lawn services, landscape architects, arborists, or other.

Overall business PROFILE. The vast majority of respondents (95\%) operates from only one location and has been in business less than 6 years $(77.7 \%)$. In contrast, a survey of the Illinois green industry showed the average tenure of business was 24 years for producer-type businesses and 20 years for service-type (design, construction, maintenance) businesses (Campbell, 2001). A 2004 national survey of landscape contractors revealed the average tenure of these businesses was almost 14 years (Wisniewski, 2004).

A majority $(87 \%)$ of Iowa green industry businesses are family-owned and $86 \%$ had at least one family member as a paid employee. A single paid family member was the most common response $(33 \%)$ followed by two paid family members $(22 \%)$ and an equal number $(22 \%)$ of cases in which no family members were paid for their work at the business. Only 9\% reported more than four paid family members. In comparison, $87 \%$ of Illinois green industry businesses were family-owned with an average of two paid family members per business (Campbell, 2001).

The principal owners of these Iowa businesses were overwhelmingly white $(97 \%)$, predominantly male (65\%), and were mostly between 41 and 60 years old $(66 \%)$. The next largest age group was 20 to 40 years (17\%) followed by respondents older than 60 years $(16 \%)$. Six percent of respondents in the over 60 years age group were older than 70 years.

Employment. There are an estimated 11,277 jobs within Iowa's green industry. Businesses in the retail and service sectors reported a similar total number per firm of male and female employees, and a majority of businesses have fewer than five fulltime, part-time, and seasonal employees. The wholesale sector reported more full-time and seasonal employees (Table 1). Nationally, nursery and greenhouse businesses average almost 15 (combined male and female) full-time workers and 13 (combined male and female) part-time workers (USDA, 2004). In Iowa, when seasonal employees are combined with the number of full-time employees, the size of the workforce essentially doubles, highlighting the seasonality of the green industry. This pronounced and inherent seasonality in business activity is evidenced by the majority of sales occurring in the spring and summer (Hall et al., 2005; Henricks, 2005). Not surprisingly, respondents reported May (45.3\%) and June $(11.9 \%)$ as months with peak employment. When asked if labor costs were low, appropriate, high, or do not know when measured against worker productivity, $51 \%$ felt they were appropriate but $30 \%$ said they did not know.

The total number of U.S. citizens employed by Iowa green industry businesses ranged from one to 67; however, a majority (55\%) of companies employed one to five U.S. citizens, $18 \%$ employed five to 10 , and $14 \%$ employed more than 10 . Unfortunately, insufficient responses to questions relating to ethnicity and resident or nonresident alien status of employees made it impossible to characterize this important segment of the workforce.

SALES AND ReCEIPTS. Gross receipts are defined as the total sales for a business during the year less returns and allowances. The largest percentage $(42 \%)$ of respondents had $\$ 50,000$ or less in total gross receipts, whereas $4 \%$ had gross receipts of greater than $\$ 1$ million (Fig. 1). In 2004, Iowa's green industry had an estimated \$311.5 million in total gross receipts for products and services. In comparison, the third (Illinois) and fourth (Wisconsin) largest green industry states in the midwestern United States had $\$ 3.2$ billion and $\$ 1.5$ billion, respectively, in total gross receipts for products and

Table 1. Average number of employees working in different sectors ${ }^{\mathrm{z}}$ of Iowa's green industry $(\mathrm{n}=117) . \mathrm{y}$

\begin{tabular}{lccc}
\hline Position/gender & $\begin{array}{c}\text { Retail sector } \\
\text { employees } \\
\text { (avg no.) }\end{array}$ & $\begin{array}{c}\text { Wholesale sector } \\
\text { employees } \\
\text { (avg no.) }\end{array}$ & $\begin{array}{c}\text { Service sector } \\
\text { employees } \\
\text { (avg no.) }\end{array}$ \\
\hline $\begin{array}{l}\text { Full-time } \\
\quad \text { Male }\end{array}$ & 2.18 & & \\
$\quad \begin{array}{l}\text { Female } \\
\text { Part-time }\end{array}$ & 2.17 & 12.00 & 2.22 \\
$\quad$ Male & 1.72 & 6.75 & 1.46 \\
Female & 2.51 & 2.00 & 1.92 \\
Seasonal & & 2.50 & 2.16 \\
$\quad$ Male & 3.62 & 7.75 & 3.95 \\
$\quad$ Female & 3.76 & 15.25 & 2.92 \\
Total & & & 4.75 \\
Male & 4.08 & 20.25 & 3.04 \\
Female & 4.96 & 23.25 & \\
\hline
\end{tabular}

${ }^{2}$ Retail $=$ majority of business $/$ products sold to end user; wholesale $=$ majority of business $/$ products sold to retailers or contractors; service $=$ majority of business $/$ products are service-oriented (landscape installation, maintenance, hardscape installation, and so on).

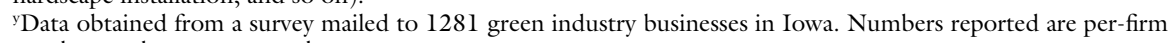
numbers and not sector totals.

${ }^{x}$ Part-time employees defined as year-round employees with less than $40 \mathrm{~h}$ per week. Seasonal employees defined as those hired on a temporary basis normally in the spring and summer only. 


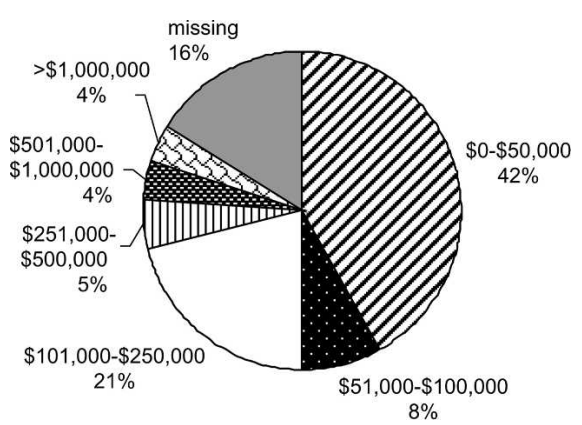

Fig. 1. Proportion of Iowa green industry companies categorized by total 2003 gross receipts $(n=98)$. Data obtained from a survey mailed to 1281 Iowa green industry businesses.

services (Campbell, 2001;Wisconsin Agricultural Statistics Service, 2004).

Because a large portion of green industry revenue is generated from services (Hall et al., 2005), respondents were asked about the percentage of gross receipts they earned from services. Of the $43 \%$ who said they offered services, the amount of service-generated revenue ranged from less than $\$ 20,000(24 \%), \$ 21,000$ to $100,000(22 \%), \$ 100,000$ to $250,000(20 \%)$, to greater than $\$ 250,000(6 \%)$ of gross receipts. Twenty-eight percent of respondents did not respond to this question. Landscape installation and general landscape maintenance were the primary services accounting for the largest percentage of service-generated revenue in Iowa (Table 2). Similarly, in Illinois, Wisconsin, and the United States, landscape installation and landscape maintenance accounted for the majority of receipts from services (Brakeman, 2003; Campbell, 2001; Wisconsin Agricultural Statistics Service, 2004).

Table 2. Comparison of proportion of gross receipts from Iowa firms offering services to Illinois, Wisconsin, and the United States. ${ }^{\mathrm{z}}$

\begin{tabular}{|c|c|c|c|c|}
\hline \multirow[b]{2}{*}{ Type of service } & \multicolumn{4}{|c|}{ Proportion of gross receipts (\%) } \\
\hline & Iowa & Illinois $^{y}$ & Wisconsin ${ }^{x}$ & United States $^{w}$ \\
\hline Landscape installation & 66 & 35 & 47 & 55 \\
\hline General landscape & & & & \\
\hline maintenance & 15 & 33 & 15 & 37 \\
\hline Tree maintenance & 3 & 8 & 10 & - \\
\hline Interiorscape maintenance & 2 & 3 & 1 & - \\
\hline Other & 14 & 21 & 27 & 7 \\
\hline
\end{tabular}

${ }^{2}$ Data from Iowa firms obtained from a survey mailed to 1281 Iowa green industry businesses.

yCampbell, 2001.

${ }^{x}$ Wisconsin Agricultural Statistics Service, 2004

wrakeman, 2003

Many types of plants are sold by green industry businesses, and in Iowa, $70 \%$ of respondents sold products directly to the consumer or end user. For these businesses, an average of $62 \%$ of their gross receipts came from sales to end users. The producer sector of Illinois' green industry also averaged $62 \%$ of sales to end users (Campbell, 2001). The relatively small size of Iowa's green industry, with its limited number of growers, was reflected in that only $8 \%$ of respondents grew all of the plants in their inventory, whereas almost $40 \%$ purchased all of their plants from outside sources. For nongrowers in the Illinois green industry, $47 \%$ of total gross receipts came from plants purchased outside of Illinois, whereas $53 \%$ came from plants purchased from Illinois growers (Campbell, 2001).

A diverse mix of plants is sold by Iowa's green industry. Annual bedding plants accounted for the largest percentage $(19.4 \%)$ of gross receipts followed by trees $(18.2 \%)$, shrubs $(15.2 \%)$, perennials $(14.3 \%)$, and cut flowers (11.9\%) (Table 3). In Illinois, cut flowers accounted for $33 \%$ of gross receipts followed by annual bedding plants $(17 \%)$, potted flowering or foliage plants $(16 \%)$, perennials $(8 \%)$, and trees (7\%) (Campbell, 2001). On a national scale, nursery crops (including Christmas trees) accounted for $66.7 \%$ of wholesale sales followed by annual bedding $(11.8 \%)$, potted flowering or foliage plants $(9.3 \%)$, perennials $(4.3 \%)$, and cut flowers (2.6\%) (USDA, 2006).

Value of assets. Respondents estimated the total fair market value of equipment, facilities, and plant inventory at the end of 2004 to quantify the value of their assets. Reported values ranged from $\$ 0$ to 18 million

Horlechnology · October-December 2007 17(4)
(Table 4). Total land value varied from $\$ 0$ to 10 million. An almost equal number of companies had no assets (land, equipment, or plants) at the end of the year as those that had greater than $\$ 500,000$. In 2001 , the total estimated fair market value of the Illinois green industry assets was $\$ 3.2$ billion with $\$ 1.8$ billion attributed to the producer sector and $\$ 1.4$ billion attributed to the service sector.

BUSINESS SUCCESS FACTORS. Using a scale of 1 to $5(1=$ not at all limiting, 5 = extremely limiting), respondents ranked the degree to which 23 different factors limited their company's ability to expand operations or remain competitive in the previous 5 years (Table 5 ). The most limiting factor for the retail and wholesale sectors was the ability to compete with "box stores" or mass merchandisers with average ranks of 3.60 and 3.75 , respectively. The retail sector also considered geographic location (3.11), ability to control raw material costs (3.04), capital availability (3.03), and ability to hire qualified personnel (3.00) as limiting factors. The wholesale sector had few factors they considered limiting. The service sector ranked the ability to hire qualified personnel as their most limiting factor (3.25) followed by scale or size of business (3.18), geographic location (3.12), ability to compete with box stores (3.06), and ability to retain quality personnel $(3.00)$. Across all three industry sectors, only seven of the 23 business success factors ranked 3.00 or greater, suggesting most of the factors were not very limiting. Recent surveys of

Table 3. Proportion of wholesale gross receipts by commodity for Iowa's green industry $(n=108) .^{z}$

\begin{tabular}{lc}
\hline Commodity & $\begin{array}{c}\text { Proportion of gross } \\
\text { receipts (\%) }\end{array}$ \\
\hline Annuals & 19.4 \\
Trees & 18.3 \\
Shrubs & 15.2 \\
Perennials & 14.3 \\
Cut flowers & 11.9 \\
Potted plants & 10.0 \\
Other & 4.2 \\
Vegetable plants & 2.9 \\
Turf & 1.8 \\
Christmas trees & 1.0 \\
Seed & 1.0 \\
\hline${ }^{2}$ Data obtained from a survey mailed to 1281 Iowa \\
green industry businesses.
\end{tabular}


Table 4. Proportion of survey respondents with estimated total fair market value (including plant inventory, equipment, and facilities) and total land value categorized by amount. ${ }^{\mathrm{z}}$

\begin{tabular}{|c|c|c|c|c|c|c|}
\hline & \multicolumn{6}{|c|}{ Proportion of survey respondents (\%) } \\
\hline & $\mathbf{0}$ & $\$ 1-\$ 10,000$ & $\$ 10,001-\$ 50,000$ & $\$ 50,001-\$ 100,000$ & $\$ 100,001-\$ 500,000$ & $>\$ 500,000$ \\
\hline Market value $(\mathrm{n}=87)$ & 6.8 & 21.3 & 17.9 & 5.9 & 17.0 & 5.1 \\
\hline
\end{tabular}

${ }^{2}$ Data obtained from a survey mailed to 1281 Iowa green industry businesses.

the Illinois and Wisconsin green industries reported the ability to hire skilled labor and supervisors and capital availability as the most limiting factors to business success (Campbell, 2001; Wisconsin Agricultural Statistics Service, 2004).

Ninety-three percent of respondents reported their strongest competitors are within Iowa. Respondents compared the relative strength $(1=$ much weaker, 5 = much stronger) of their company with their competitors, and across all three sectors, customer perception of product quality ranked the highest (Table 6). Respondents in the retail and service sectors reported they were stronger than their competitors in the areas of customer perception of service and the ability to meet customer needs. In the wholesale sector, respondents reported they were stronger than their competitors in the areas of customer perception of product quality, the ability to meet customer needs, and size of business, ranking each at 3.75. These perceived strengths bode well for Iowa's green industry businesses when considered with the results from the 2004 Garden Writers of America survey, which reported $56 \%$ of people who shop at local retailers value quality and $24 \%$ of shoppers value a trained and educated sales staff (National Gardening Association, 2004).

FUTURE BUSINESS EXPECTATIONS. Respondents were asked to anticipate changes expected in 2005 and in 2010 regarding number of employees, sales, and expenses. In the short term (2005), 61\% of respondents expected peak employment level to stay about the same and $47 \%$ expected annual gross payroll to stay about the same, whereas a majority (61\%) expected annual gross sales to increase. On the question of total annual expense, excluding labor, $38 \%$ expected this to stay about the same, whereas $45 \%$ expected to see an increase in this area. Looking forward to 2010 , most respondents expected to see increases in all four areas: peak

Table 5. Average rating per firm of the top $\mathbf{1 5}$ business success factors for different sectors for Iowa's green industry $(n=108) .^{z}$

\begin{tabular}{lccc}
\hline & \multicolumn{3}{c}{ Avg rating (1-5 scale) } \\
\cline { 2 - 4 } Business success factor & $\begin{array}{c}\text { Retail } \\
\text { sector }^{\mathbf{y}}\end{array}$ & $\begin{array}{c}\text { Wholesale }^{\mathbf{y}} \text { sector }^{\mathrm{x}} \\
\text { Ability to compete with "box stores" }\end{array}$ & $\begin{array}{c}\text { Service } \\
\text { sector }^{\mathbf{x}}\end{array}$ \\
Ability to hire qualified personnel & 3.60 & 3.75 & 3.06 \\
Capital availability & 3.00 & 2.50 & 3.25 \\
Ability to control raw material costs & 3.03 & 1.80 & 2.96 \\
Ability to retain qualified personnel & 3.04 & 2.80 & 2.90 \\
Geographic location & 2.79 & 1.75 & 3.00 \\
Staff experience/knowledge of horticulture skills & 3.11 & 2.00 & 3.12 \\
Scale or size of business & 2.68 & 2.00 & 2.90 \\
Scope or breadth of operations & 2.55 & 2.20 & 3.18 \\
Ability to control product pricing & 2.47 & 2.40 & 2.93 \\
Staff experience/knowledge or "people" skills & 2.60 & 2.60 & 2.63 \\
Market placement/niche & 2.38 & 1.75 & 2.70 \\
Ability to control personnel costs & 2.35 & 2.25 & 2.43 \\
Land availability or quality & 2.27 & 2.50 & 2.18 \\
Customer perceptions of company & 2.13 & 1.20 & 2.36 \\
\hline Data obs & 2.01 & 1.60 & 2.34 \\
\hline
\end{tabular}

${ }^{2}$ Data obtained from a survey mailed to 1281 Iowa green industry businesses.

${ }^{\mathrm{y}} \mathrm{l}=$ not at all limiting, 5 = extremely limiting.

${ }^{x}$ Retail $=$ majority of business $/$ products sold to end user; wholesale $=$ majority of business $/$ products sold to retailers or contractors; service $=$ majority of business $/$ products are service-oriented (landscape installation, maintenance, hardscape installation, and so on).

Table 6. Average rating per firm of relative strength of different sectors of Iowa's green industry compared with competitors $(n=108) .^{\mathrm{z}}$

\begin{tabular}{lccc}
\hline & \multicolumn{3}{c}{ Avg rating (1-5 scale) $^{\mathbf{y}}$} \\
\cline { 2 - 4 } Company strength & $\begin{array}{c}\text { Retail } \\
\text { sector }^{\mathbf{x}}\end{array}$ & $\begin{array}{c}\text { Wholesale }^{\text {sector }^{\mathbf{x}}} \\
\text { Customer perception of product quality }\end{array}$ & $\begin{array}{c}\text { Service } \\
\text { sector }^{\mathbf{x}}\end{array}$ \\
Customer perceptions of service & 4.46 & 3.75 & 4.21 \\
Ability to meet customer needs & 4.19 & 3.50 & 4.15 \\
Customer perceptions of company & 4.02 & 3.75 & 3.96 \\
Staff experience/knowledge & 3.89 & 3.50 & 3.80 \\
Market placement/niche & 3.80 & 3.66 & 3.59 \\
Prices & 3.36 & 2.75 & 3.59 \\
Ability & 3.31 & 3.25 & 3.30 \\
Breadth of operations & 3.07 & 2.75 & 3.56 \\
Branding/advertisement & 2.90 & 3.25 & 3.12 \\
Geographic location & 2.98 & 2.66 & 2.90 \\
Size of business & 2.75 & 3.50 & 2.87 \\
\hline
\end{tabular}

${ }^{2}$ Data obtained from a survey mailed to 1281 Iowa green industry businesses.

${ }^{y} 1=$ much weaker, 5 = much stronger.

${ }^{x}$ Retail $=$ majority of business $/$ products sold to end user; wholesale $=$ majority of business $/$ products sold to retailers or contractors; service = majority of business/products are service-oriented (landscape installation, maintenance, hardscape installation, and so on).

employment (44\%), annual gross payroll $(61 \%)$, annual gross sales $(62 \%)$ and total annual expenses (64\%). These upward predictions during the next 5 years reflect the expected growth in this segment of Iowa's agriculture (Klein, 2003).

Professional development. Professional development in the form of meetings, symposia, and conferences 
is important to members of Iowa's green industry as evidenced by the relatively high percentage $(63 \%)$ of respondents participating in these activities. A majority of respondents said they participate in professional development activities in Iowa (88\%), whereas $60 \%$ participate in these activities throughout the midwestern United States and $21 \%$ participate in activities outside of the Midwest. Professional development sponsored by state trade or grower associations $(69 \%)$ and by Iowa State University Extension (68\%) was the most popular sources of training for our respondents. Providing appropriate and timely educational opportunities for green industry professionals is an important role of the cooperative extension service. Developing collaborative programs between state associations and extension is a viable and efficient way to meet this need (VanDerZanden et al., 2006).

\section{Conclusion}

The economic impact of Iowa's green industry and allied sectors associated with the industry in 2004 was $\$ 538.2$ million, indicating that the green industry is an important part of Iowa's overall economy. Although size and type of businesses varied, a majority of respondents had only one location, were family-owned, had been in business less than 6 years, and had less than 10 employees in each of the categories (full-time, part-time permanent, and seasonal). These varied businesses offered a diverse mix of plants, most of which are purchased from outside sources, and $43 \%$ of businesses also offered some type of landscape service. A majority of respondents expected their business to expand in relation to number of employees, gross payroll, sales and total expenses by 2010. Respondents participating in our study were generally optimistic and identified only a few factors that could be limiting to business success. Of the limiting factors, the availability of skilled labor and availability of capital were also reported as limitations by other states with larger green industries than Iowa (Campbell, 2001; Scoggins et al., 2004; Wisconsin Agricultural Statistics Service, 2004).

The ability to compete with "box stores" was ranked as the most limiting factor by Iowa respondents in the retail and wholesale sectors. One way Iowa companies can improve their competitive edge is to provide their clientele services or products not available at "box stores." Research has shown that consumers will seek out and purchase from independent nursery and garden centers when they value trained and educated sales staff and high-quality products (Khatamian and Stevens, 1994; Makus et al., 1992; National Gardening Association, 2004; Safley and Wohlgenant, 1995). For example, in Illinois, 26\% of homeowners reported receiving most of their information on ornamental plants from staff at retail nurseries and garden centers (Campbell, 2001). Respondents already note they perceive themselves as stronger than their competitors in terms of customer perception of product quality and service and their ability to meet customer needs. Promoting and enhancing these strengths should help them compete with box stores.

Growing a skilled workforce will help position Iowa's green industry for further expansion. To date, industry members from Iowa have participated in professional development activities within the state and region and will likely continue to seek additional professional enrichment opportunities as their businesses grow. Although the needs for educational programming will vary based on business type and size, basic and updated research-based information on crop production, pest and disease management, and business management are always relevant and in demand (Scoggins et al., 2004). Educational programs developed and delivered by universities, industry associations, or cooperative extension can be an important part of the industry's growth.

\section{Literature cited}

Brakeman, L. 2003. 2003 State of the industry report. 3 Nov. 2006. <http:// www.pestcontrolmag.com/landscape/ article/articleDetail.jsp?id=70209url>.

Campbell, G.E. 2001. The Illinois green industry: Economic impact, structure, characteristics. Department of Natural Resources and Environmental Sciences Report 2001-01. College of Agriculture and Environmental Sciences, Univ. Illinois, Champaign-Urbana.

Hall, C.R., A.W. Hodges, and J.J. Haydu. 2005. Economic impacts of the green industry in the United States. 3 Nov.
2006. <http://www.utextension.utk. edu/hbin/greenimpact.html>.

Henricks, M. 2005. Toil in the soil: Running a garden-related biz. 3 Nov. 2006. <http://www.realestatejournal.com/ homegarden/20051012-henricks.html>.

Khatamian, H. and A. Stevens. 1994. Consumer marketing preferences for nursery stock. J. Environ. Hort. 12:47-50.

Klein, W. 2003. More Iowans involved in horticulture. Iowa Horticulturist 20:18-19.

Likert, R. 1932. A technique for measurement of attitudes. Arch. Psychol. (Frankf.) 140:5-55.

Makus, L.D., J.C. Foltz, J.F. Guenthner, and R.R. Tripepi. 1992. Product and service attributes related to marketing nursery stock. HortTechnology 2:483-487.

National Agricultural Statistics Service. 2001. Iowa's turfgrass industry. Iowa Agr. Stat. Serv., Des Moines.

National Agricultural Statistics Service. 2002. Iowa commercial horticulture survey: Edible food crops. Iowa Agr. Stat. Serv., Des Moines.

National Gardening Association. 2004. National Gardening Association's 2004 Gardening Survey. Natl. Gardening Assn., South Burlington, VT.

Safley, C.D. and M.K. Wohlgenant. 1995. Factors influencing consumers' selections of garden centers. J. Agribusiness 13:33-50.

Scoggins, H.L., J.G. Latimer, and V.T. Barden. 2004. The Virginia commercial greenhouse industry-Current practices and future needs assessment. HortTechnology 14:109-114.

U.S. Department of Agriculture. 2004. Floriculture and nursery crops situation and outlook yearbook. 3 Nov. 2006. <http://usda.mannlib.cornell.edu/usda/ ers/98004/2004/03003-2004.doc $>$.

U.S. Department of Agriculture. 2006. Floriculture and nursery crops yearbook. 3 Nov. 2006. <http://usda.mannlib. cornell.edu/usda/current/FLO/FLO09-22-2006.pdf>.

VanDerZanden, A.M., L. McMahan, N. Bell, P. Ries, P. Williams, and A. McAuliffe. 2006. A collaborative effort to train green industry professionals. HortTechnology 16:143-145.

Wisconsin Agricultural Statistics Service. 2004. Economic impact of Wisconsin's green industry. Wisconsin Dept. of Agr., Trade and Consumer Protection-Wisconsin Agr. Stat. Serv. Bul. 0151, Madison.

Wisniewski, N. 2004. The state of the industry. Lawn Landscape 25:S1-S23. 